Research Article

\title{
Teaching Russian Culture via English: Implications, Objectives and Challenges
}

\author{
I.L. Lebedeva \\ M. Lomonosov Moscow State University (MSU) \\ 1 Leninskie Gory, bldg. 13-14, Moscow, 119991, Russian Federation
}

The article focuses on the issues related to the specifics of teaching the Russian Culture via English course introduced as a part of Masters in Linguistics degree program at the Faculty of Foreign Languages and Area Studies of Lomonosov Moscow State University (MSU) in 2016. The need for the course stems from the fact that the era of pluricentric English calls for a new type of globally competent and competitive Russian linguists, teachers, and teacher trainers of English able to express their national identity as well as to transmit, promote, and teach national culture through English functioning as a lingua franca, specifically, through the national variety of English, that is Russian English. The course aims at fostering students' national self-awareness and enhancing their ability to reflect upon their own culture, culture of others as well as culture in general. The article also tackles such aspects as the course syllabus and objectives, its teaching techniques, and materials, as well as challenges that students might face.

Key words: Russian English, Russian culture, teaching Russian culture through English, English as an International Language (EIL) / Global English, English as a lingua franca, intercultural communication

\section{Article history:}

Received: 06.06.2020

Accepted: 29.09.2020

Moderator: U.M. Bakhtikireeva

Conflict of interests: none

\section{For citation:}

Lebedeva, I.L. 2020. "Teaching Russian Culture via English: Implications, Objectives and Challenges". Polylinguality and Transcultural Practices, 17 (4), 534-541. DOI 10.22363/2618897X-2020-17-4-535-541

(С Лебедева И.Л., 2020

This work is licensed under a Creative Commons Attribution 4.0 International License https://creativecommons.org/licenses/by/4.0/ 


\title{
Преподавание русской культуры на английском языке: цели, задачи и трудности
}

\author{
И.Л. Лебедева \\ МГУ имени М.В. Ломоносова \\ Российская Федерация, 119991, Москва, Ленинские горы 1, стр. 13 (IV гуманитарный корпус)
}

\begin{abstract}
В настоящее время в рамках концепции плюрицентричности английского языка в современной системе высшего образования на первый план выходит проблема подготовки универсальных специалистов-лингвистов, способных свободно говорить о явлениях родной культуры на своем варианте английского языка, используя его как средство вторичной самоидентификации. Кроме того, в российской системе образования все большее распространение получает принцип изучения иностранных языков и культур в приложении к русскому языку и русской культуре. Данные предпосылки вместе с необходимостью поднять общий уровень компетенции студентов в области родной культуры легли в основу создания уникального курса «Русская культура на иностранном языке», читаемого магистрам второго года обучения по специальности «Лингвистика» на факультете иностранных языков и регионоведения МГУ имени М.В. Ломоносова с 2016 года. Помимо причин, приведших к созданию курса, статья также охватывает круг вопросов, касающихся особенностей преподавания данного курса, его целей и задач, а также языковых, коммуникативных и профессиональных компетенций, формируемых в его рамках.
\end{abstract}

Ключевые слова: русский вариант английского языка, русская культура, преподавание русской культуры на английском языке, английский язык как язык международного общения, английский язык как лингва франка, межкультурная коммуникация

\section{История статьи:}

Дата поступления в редакцию: 06.06.2020

Дата принятия к печати: 29.05.2020

Модератор: У.М. Бахтикиреева

Конфликт интересов: отсутствует

\section{Для цитирования:}

Лебедева И.Л. Преподавание русской культуры на английском языке: цели, задачи и трудности // Полилингвиальность и транскультурные практики. 2020. Т. 17. № 4. С. 535-541. DOI 10.22363/2618-897X-2020-17-4-535-541

\section{Introduction}

As has been discussed in the literature, the era of translingualism and transculturalism have made teachers, teacher trainers and educators of English aware of an array of new challenges closely related to teaching English not only as a vehicle of international and intercultural communication but rather as a means of transmitting and fostering national 
cultural identity [1]. Firstly, this happened due to the noticeable shift in the landscape of English teaching we are witnessing both worldwide and in Russia: the shift from teaching English as a Foreign Language (EFL) based on the norms of British or American linguacultures to teaching English as an International Language (EIL) based on the pluricentric principles of World Englishes [2], imbedded in the theoretical framework of the three concentric circles designed by Braj Kachru back in the 1960s [3]. Accordingly, EIL - being underpinned by various cultures which in their turn underpin the varieties represents a diversity of Anglophone varieties, Russian English included. Despite the fact that the status of Russian English is still a subject of an ongoing domestic debate, most scholars agree on the existence of the Russian variety of English, which can be identified by a specific set of distinctive linguistic as well as non-linguistic features (functional, pragmatical, etc.) (see [4-6]). Moreover, Russian English generally functions not only as a means of communication for educated Russians in various settings, but also serves as a tool for expressing Russian identity and Russian culture - that is, Russian worldviews, lifestyles, and values - in a word, everything that constitutes Russianness. Due to these factors, the Russian variety of English is recognizable not only by Russian users of English, but also by the many speakers of other English varieties, even in the Instagram [7].

Secondly, the Russian national educational landscape has gradually started to adopt the idea of teaching World Englishes and cultures of target countries in tight connection with national culture and values perceiving English as a tool that ensures and fosters understanding Russian cultural and historic heritage as well as lifestyle and worldview rather than Anglophone cultures and values. S.G. Ter-Minasova has emphasized the necessity of teaching English-learning Russian students their own culture through English, including aspects related to the ways of conveying information concerning the Russian national culture and values, means and methods of transmitting Russianness and Russian identity via English viewing these issues as cornerstones of international communication due to the fact that speakers of other varieties of English when communicating in English with Russians are in the first place interested in learning more about Russian culture and Russian world rather than their own [8]. However, the prevailing majority of English textbooks in Russia, specifically school textbooks or textbooks created by Russian material writers, are primarily focused on Anglophone cultures rather than on non-Anglophone ones, including Russian.

Thirdly, the above-mentioned approach to teaching English endorses the prime objective of state policy in the field of education in modern Russian society that aims at raising true patriots and loyal citizens through school and university systems, which presupposes a thorough knowledge and understanding of Russian culture and values, as well as the ability to express them via a Russian variety of English. The above-mentioned aim is also reflected in the Educational Standard of Lomonosov Moscow State University 1 for the Master's Program in Linguistics, as MA program graduates are to possess professional competences and skills necessary for raising global awareness regarding Russia, promoting Russian culture, and preserving the Russian heritage (Educational

1 Lomonosov Moscow State University is a separate educational entity that has the right to develop, design, and instill/implement its own educational standards and policy independently from the Ministry of Education. 
standard by Lomonosov MSU for the Master's program in Linguistics, July 22, 2011. № 729 (№ 3)).

Fourth and the last, skills and competences of such nature are specifically crucial for linguists, future teachers, and teacher trainers so that they become globally competent and competitive professionals who, being aware of the linguacultural characteristics of Russian English, are able to utilize English as a global language when talking about their country and culture. Moreover, they are not only expected to incorporate those practices in their future professional lives on a daily basis, but also to pass them on to their own students - aspiring English teachers - in the future.

Hence, the outlined implications have led to the creation of the required course Russian Culture through Foreign Languages in the Master's Degree Program in Linguistics in the Faculty of Foreign Languages and Area Studies of Lomonosov Moscow State University since 2016.

\section{Discussion}

The required course Russian Culture through Foreign Languages is taught within Master's degree program to students whose specialization is Linguadidactics of Foreign Language Teaching in Tertiary Education at the Faculty of Foreign Languages and Area Studies at Lomonosov Moscow State University (MSU). The course was taught for the first time in the fall of 2016 to English and Spanish majors. However, the present paper deals with the course in English introduced to the second-year English Master's majors; therefore, I am going to refer to it as Russian Culture via English. The course covers one term and is taught on a weekly basis which amounts to 36 contact hours, and a pass/not pass system is used for grading. Since 2018 a modified version of the course has been introduced as an elective to third-year BA students majoring in teaching English, as well as to English-speaking exchange students. The course is predominantly taught in English and is a combination of theory and practice, in which micro-lectures are followed by practical in-class and out-of-class tasks and activities that exercise a communicative approach. The aim of the course is to build and develop skills vital for transmitting information about Russian culture and Russianness via English as a global language as well as a secondary means for expressing self-identity via the Russian variety of English. The objectives of the course are as follows: to familiarize students with linguistic and extralinguistic aspects of Russian English as a variety within the English as an International Language paradigm; to develop skills vital for transmitting information about their country and culture during intra- and international communication; to strengthen overall knowledge in terms of national self-identification, history, culture, and lifestyles, as well as to foster their ability to reflect upon their own culture, cultures of others, and culture in general, while using English as a tool for education.

Due to the fact that the course is relatively new, the number of available textbooks is rather limited. The primary textbook is Russian Culture Through English by V.V. Kabakchi, which is accompanied by the monolingual dictionary The Dictionary of Russia by the same author, which comprises more than 2500 Russian terms [9; 10]. The textbook boasts a wide range of authentic texts dealing with Russian culture from a number of reliable sources, such as The Cambridge Encyclopedia of Russia and Encyclopedia Britannica written 
by prominent authors, such as John Reed and Hendrick Smith, as well as mass-media and scholarly texts in the field of World Englishes, including Russia-based sources such as The Moscow Times or The St. Petersburg Times, Russian travel guidebooks, and excerpts of works by famous Russian authors writing in English. Contemporary authentic materials that reflect Russian culture, worldview, and/or current home affairs from various media and internet sources such as YouTube and TED.com are also used for in-class activities and home assignments. I select texts that present controversial, thought-provoking issues and attitudes that trigger discussion and debates, as well as enhance critical thinking skills, apart from fulfilling the above-mentioned course goals. Needless to say, the texts lie within the scope of the students' academic as well as professional interests, thus cannot help but benefit the students immensely.

Overall, the course consists of three modules: 1. Culture and Ways of Its Description; 2. History of Russia; 3. Russian Identity and Lifestyles.

The first module, Culture and Ways of Its Description, examines the core patterns of English as a lingua franca as well as Russian English usage, which is characterized by specific manifestations of Russianness at all linguistic levels, including pronunciation, vocabulary, grammar, stylistics, and even orthography, in which variations occur because of the absence of one common system of transliteration of the Cyrillic alphabet, which poses various challenges. Hence, any English text describing Russian culture and/or lifestyles can be written via various systems for transliterating Cyrillic alphabet into English, which leads to the infinite number of spelling variations of one and the same word (e.g., matryoshka, matreshka, matrioshka, matryoska, matrëska). Therefore, it is necessary to familiarize students with all these systems and variations with the help of specific sites, for example, Translit.ru which offers an online transliteration service with a variety of systems to choose from. Moreover, at this stage, students are familiarized with the potential of Russian-English language play, including bilingual creativity, such as bilingual punning, bilingual lexical hybridization as well as mock Englishization and bilingual multimodal play [6].

In addition, Module 1 offers practical tasks and activities aimed at training various skills necessary for describing any culture in English. This module does require previous knowledge of the subject from the Bachelor's degree program in regard to the most common types of translation techniques such as transliteration, transplantation, transcription, and/or translation. However, these techniques are revised in the light of their applicability to culture-neutral and culture-specific vocabulary, such as "culturonyms" (culture-marked designations), "idionyms" (internal culture-loaded vocabulary), and "xenonyms" (foreign culture-loaded vocabulary) [10]. At this point, such models of translation as calque/loan translation, descriptive translation (the "Russian Doll model"), analogical translation, and transformations, including explications, are examined.

The above-mentioned theoretical implications and practical methods are applied to the texts from Module 2 - History of Russia. On balance, the aim of Module 2 is to build skills integral for the usage of the Russian variety of English as a secondary means of expressing cultural self-identity [10], which is challenging without actualizing historical context. Interestingly, Module 2 is virtually the only possibility for Russian students to utilize English when examining Russian history as all the other courses devoted to history and Russian culture within BA and MA programs are taught primarily in Russian. 
Basically, students discuss every major period of Russian history comparing the ways of its presentation and interpretation in national and foreign sources in English, including Wikipedia and Russiapedia. At this point, students also encounter challenges related to reliability and credibility of sources, which triggers critical thinking skills necessary for identifying misinformation, propaganda and such.

Module 3, Russian Identity and Lifestyles, is aimed at perfecting the earlier-acquired skills necessary while describing such domains of Russian culture as geography, religion, literature and arts, city life, food, health and the healthcare system, raising children, education, traditions and superstitions, mythology, and typical traits of the Russian character. The module focuses on extralinguistic, pragmatic, and conceptual characteristics of the Russian variety of English that stem from the Russian mentality and identity, as well as the users' first language, Russian. The most controversial, ambiguous, and sensitive topics are selected in order to provoke discussions that demand a thorough explication of one's point of view with supporting arguments relying on specific examples. Likewise, Module 3 addresses issues related to auto- and heterostereotypes, i.e. stereotypes of Russians shared by Russians and non-Russians respectively, specifically to topics that are deeply rooted in the Russian lifestyle and mindset, which lead to a better understanding of students' own identities as well as to sharpening their critical thinking skills. Take, for example, traditional Russian prejudices and superstitions as well as typical healthcare beliefs and medical diagnoses which are generally unfamiliar to the rest of the world (e.g. vegetovascular dystonia; draughts and cold drinks as causes of colds; the idea of vitamin deficiency after winter), food choices of pregnant women (keeping to a strict diet) and parental attitudes (overprotection and overdressing toddlers for the weather) and other important issues. MA students as future teachers, participants of intercultural communication and parents raising bilingual children in multilingual world have to be aware of these challenges and differences. Moreover, the students are expected to practice their debating skills on these issues, relying both on the knowledge gained during the bachelor's degree programs, their own experience and their thesis projects.

The last in-class challenge the students encounter during the course is identical to the very first one. They are asked to identify who a/the typical Russian is and explain if they consider themselves Russians and why. As experience shows, students cope with this task much better at the end of the course.

Overall, during the course students have to make three presentations dealing with one Russian historical period or figure, one Russian region or oblast, and one Russian tradition. The target audience of the presentations is speakers of different varieties of English unfamiliar with Russia, Russians, and Russian language.

To be eligible for a pass, the students are to make a final presentation in English focusing on any domain of the Russian landscape (in the most broad meaning) aimed at an English-speaking audience familiar with Russia only by hearsay. The students are expected to demonstrate the acquired skills and methods useful for the introduction, description and interpretation of the Russian culture. The topics of presentations range from traditional subjects (e.g., favorite Russian artists, scientific breakthroughs, stereotypes and myths about Russians) to more unconventional issues (e.g. the popularity of the Cyrillic alphabet among designers worldwide or a characteristic depiction of Russians as villains in American or British literature and movies). 


\section{Conclusion}

To recapitulate, the Russian Culture via English course is relatively new in the Russian educational landscape, having been introduced in the fall of 2016 as a reaction to the shift in the language education paradigm based on the concept of pluricentricity of English. Questionnaire surveys conducted at the beginning and the end of each course show that MA students feel the need for the course and find it extremely beneficial. Obviously, a recent challenge we have faced recently, which the brave new online world has posed to us, is the need for an online course as well as for new textbooks and materials to be tailored for it which I am in the process of collating now.

\section{References}

1. Lebedeva, I.L. 2017. Kurs “Russkaja kul'tura na anglijskom jazyke”. Vestnik RUDN. Serija Voprosy obrazovanija: jazyki i kul'tury 14 (4): 687-693. Print. (In Russ.)

2. Proshina, Z.G. 2016. EIL ili EFL? Izmenenie bukvy ili novaja kontsepcija jazykovogo obrazovanija?" Vestnik MGU. Ser. 19: Lingvistika i mezhkul'turnaja kommunikacija 19 (4): 171-186. Print. (In Russ.)

3. Kachru, B.B. 1985 (2006). "Standards, codification and sociolinguistic realism. The English language in the Outer Circle". In R.Quirk \& H.G. Widdowson (eds), English in the World: Teaching and Learning the Language and Literatures. Cambridge: Cambridge University Press, 11-30. Reprint: K. Bolton \& B. Kachru (eds.), World Englishes: Critical Concepts in Linguistics. London \& New York: Routledge. Vol. 3: 241-269. Print.

4. Proshina, Z., and A. Eddy (eds.). 2016. Russian English. History, Functions, and Features. Cambridge: Cambridge University Press. Print.

5. Proshina, Z.G. 2019. "Elaborating on the Expanding Circle". World Englishes. 38(1-2): 233-244. DOI: 10.1111/weng.12371. Print.

6. Rivlina, A.A. 2020. "Bilingual language play and world Englishes". In Cecil Nelson, Zoya G. Proshina, and Daniel Davis (eds.), The Handbook of World Englishes (2nd edn.), Hoboken: Wiley-Blackwell, 407-429. DOI: 10.1002/9781119147282.ch23. Print.

7. Lebedeva, I.L. 2016. "IRE: a hypothesis or a theory?". Procedia - social and behavioral sciences 236: 189-193. DOI: 10.1016/j.sbspro.2016.12.063. Print.

8. Ter-Minasova, S.G. 2016. "Uchitel', uchenik, uchebnik v sovremennoy Rossii". Vestnik MGU, Ser.19: Lingvistika i mezhkul'turnaja kommunikacija 19(4): 130-138. Print. (In Russ.)

9. Kabakchi, V.V. 2002. The Dictionary of Russia (2500 Cultural Terms): Anglo-russkiy slovar' russkoy kulturnoy terminologii. Saint-Petersburg: Soyuz. Print. (In Russ.)

10. Kabakchi, V.V. 2009. Anglojazychnoe opisanie russkoy kultury $=$ Russian Culture Through English Moscow: Academia. Print. (In Russ.)

\section{Bio Note:}

Irina L. Lebedeva is a $\mathrm{PhD}$., Associate Professor for the Department of Foreign Languages and Area Studies, Lomonosov Moscow State University. E-mail: lebedevamsu@yandex.ru

\section{Сведения об авторе:}

Лебедева Ирина Леонидовна - кандидат филологических наук, доцент, доцент кафедры теории преподавания иностранных языков факультета иностранных языков и регионоведения МГУ имени М.В. Ломоносова. E-mail: lebedevamsu@yandex.ru 